\title{
An Integration of Indonesian Market for Gree Coffee: A Review from Exported and Imported Market Outlook on the Major Exported Countries
}

\author{
${\text { Agustina S. Mori Muzendi }{ }^{1 *} \quad \text { Rina Oktaviani }^{2} \quad \text { Dedi Budiman Hakim }}^{2}$ \\ 1.Departmen of Agribussiness, Faculty Agricultural, Papua University, Manowari-West Papua, PO Box 98314, \\ Indonesia \\ 2.Major of Economic Sains, Faculty of Economic and Management, Bogor Agricultural University, \\ Bogor ,16680, Indonesia
}

\begin{abstract}
The purpose of this study is to analyze the relationship between price of Indonesian green coffee beanfrom three major exporters: Brazil, Columbia, and Vietnam as well as other six major importers: the United States, Germany, Italy, Japan, Malaysia, and Singapore in the world market. Data applied in this study are a time series from 1970 to 2012, extrapolated from Food Agricultural Organization (FAO) data set. To attain the target, all data are analyzed by applying cointegrated test and error correction model (ECM). The analyses show that 1). The exported price of Indonesian green coffee cointegrated with the prices on the market that is intended to the major importers and exporters; 2). The imported price of green coffee in the United States, Germany, Japan, Malaysia, and Singapore have a significant spin-off for the short-term, but only the United States and Singapore are considered to be significant for the exported price of Indonesian coffee beans; 3). The exported price of Brazil and Vietnam possess a significant effect on the exported price of Indonesian coffee beans in both, short-term and long-term period, while the exported price from Colombian coffee beans are not significantly correlated
\end{abstract}

Keywords: Coffee price, Cointegrated test, export, Import, Error correction model

DOI: $10.7176 / \mathrm{JMCR} / 61-04$

Publication date:October $31^{\text {st }} 2019$

\section{Introduction}

Coffee is one of the important commodities traded across the world and produced more than one-third in the globe (Lewin et al. 2004; Topik 2004; Almeida et al. 2012; World Bank 2014; USDA 2016). It has been noting as an interdependent agricultural product in several countries in which statistically account for 50 percent of their export are emanating from it. In addition, coffee is also contributed significantly towards local economy and providing more incomes to the local and regional sectors for almost 125 million low-income farmers in the world. In some developing countries, coffee has been a value-laden commodity in trading-off regional economy, gaining national revenue, and functioning as a primary product for the local farmer communities (Baffes et al. 2004; bayer 2008; Cleland 2010). Currently, Indonesia is categorized as one of the largest coffee producers in the world after Brazil and Columbia with the highest rate production of robusta commodity (Siddiqui 2016). It turned out that in 2013, coffee became a national priority for exported commodity from plantation sector in Indonesia (Ditjenbun, 2012; Anwar 2014).

Statistical data point out that Indonesia's position in the international trade was in the fourth as an exporter country from the last five years (2007 to 2012) behinds Brazil, Columbia, and Vietnam in particular for robusta commodity despite a declining trend of global coffee trade about 0.3\% between 2010-1012 (World Bank 2014). Brazil and Columbia encountered the decline about $17.2 \%$ and $16.3 \%$ respectively, while Vietnam showed an increase of 32.3\% and Indonesia was 16.5\% in the same period (Sethi 2008; AEKI, 2012). Interdependency towards exported markets haveled to a fluctuation of Indonesian coffee price in spite of the exported volume indicates an increased trend in years. Such a circumstance is mainly determined by changes in the global markets whether in export or import stand point. These changes are then transmitted into Indonesian exported market on account of an integrated system of global trade market (Beyer 2008).

The engagement of countries in coffee trade schema from the international market level either as a main consumer or producer have made a laborious circumstance of changes on coffee price to be unpredictable. A fluctuation of coffee price is non-inter change able with the changing of climate, political and economic issue of each country that will straight forwardly impact on the coffee price (FAO 2009; Abdi 2016). In general, coffee market globally raised about $36.63 \%$ from 1990 to 2011 with the average of 7.036 million tons. In 2011, Brazil produced 2.7 million tons or $32.4 \%$ from the total production in the world, while Vietnam generated 1.17 million tons $(14 \%)$, followed by Indonesia around 634 thousand tons $(7.65 \%)$ and Columbia with 468 thousand tons $(5.56 \%)$. Another fundamental factor to be considered is the alteration of demands and internal changes of consumptive countries that lead to the price fluctuations (International coffee organization 2009; Dragusana et al. 2014). Fitter and Kaplinsky (2001) concluded that $60 \%$ from retailed coffee price in the international market 
considers to become an additional value of imported countries and $40 \%$ comes from both production, right and additional value of exported countries.

Base on those explained information above, the objectives of this study are: 1) to analyze the trend of green coffee prices from major exported countries as well as the price of major imported countries, 2) to analyze the long-term relationship between Indonesian exported prices of green coffee and green coffee prices from the major exported countries (3) to analyze short-term relations between the export of Indonesian green coffee price and imported green coffee price and the major exported countries.

\section{Method}

\subsection{Type and Source of Data}

This study explores secondary information through time series data from 1970 to 2012 (43 years). Data resources applied in this study are extrapolated from Food and Agricultural Organization (FAO), COMTRADE. Data cover Indonesian exported coffee price, the main price of both imported and exported countries (Brazil, Columbia, and Vietnam), and the major imported countries (United States, Germany, Italy, Malaysia, and Singapore). The price used in this study is on an average of real price of coffee for each year and such prices are then determined through world consumer price index with a based standardization of 2015.

Models applied in this study consist of two equations: first, Indonesian exported coffee price is a function of imported coffee price from the United States, Germany, Italy, Malaysia, and Singapore; second, Indonesian exported coffee price is a function of Brazilian, Columbian, and Vietnamese exported coffee prices.

\subsection{Econometrical Analysis}

\subsubsection{Stationery data test}

Cointegrated test has two pre-requirements that have to be followed: (1) rooted unit test and integration, and (2) stationary data test. Gujarati (1995) points out that non stationery data estimation will lead to super-inconsistent and tends to become a spurious regression which is failed to implement classic inferential method. To be classified as stationery data, the average of its stationer $\mathrm{E}\left(\mathrm{x}_{\mathrm{t}}\right)$ is equal to 0 (independent to $\mathrm{t}$ ), and the value of $\sigma_{t}^{2}$ is constant (the change of variants are not in line with time changes).

Stationary test is applied by using Augmented Dickey-Fuller Test (ADF) (Engle and Granger, 1987). This test based on a scholastic null-variable hypothesis that has a rooted unit. By using such an ADF test, null hypothesis and other taking decision bases used in this study arebanked on MacKinnon critical value that functioned as t-test alternative t-ratio then compared to statistically critical value in ADF t-table to know whether there are rooted units or no. If the hypothesis is accepted, then the variable is not stationery and needed to take another test which is integrated degree test in the first class (first difference) or in the second class (second difference). Integrated degree test is intended to know in which degree or difference, the observed data will be stationery.

Interpreting autoregressive model from each variable used through Ordinary Least Square (OLS) method by calculating constanta time variable.

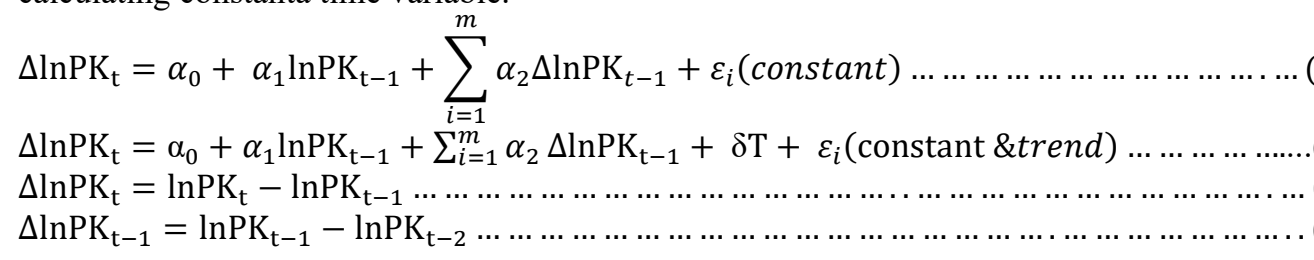

Where:

PK = Exported coffee price in Indonesia, Brazil, Colombia, as well as imported coffee price from Vietnam, United States, Germany, Italy, Japan, Malaysia, and Singapore.

$\mathrm{T}=$ Trend of time

$\mathrm{m} \quad=$ Number of lag

$\Delta \quad=$ Changes in each scale

$\varepsilon_{i} \quad=$ Residue

2.2.2. Cointegrated test

Cointegrated test can be done when data are stationery paired in the same degree or ordo. This test is carried out by looking at the equation of cointegrated regression as follow:

$$
\begin{aligned}
& \ln \text { PXKI }_{\mathrm{t}}=\delta_{0}+\delta_{1} \operatorname{lnPIKUSA}_{\mathrm{t}}+\delta_{2} \operatorname{lnPIKGER}_{\mathrm{t}}+\delta_{3} \operatorname{lnPIKITY}_{\mathrm{t}}+\delta_{4} \operatorname{lnPIKJAP}_{\mathrm{t}}+ \\
& +\delta_{5} \operatorname{lnPIKMLY}_{\mathrm{t}}+\delta_{6} \operatorname{lnPIKSGR}_{\mathrm{t}}+\varepsilon_{I I_{t}} \ldots \ldots \ldots \ldots \ldots \ldots \\
& \ln \mathrm{PXKI}_{\mathrm{t}}=\beta_{0}+\beta_{1} \ln \mathrm{PXKB}_{\mathrm{t}}+\beta_{2} \operatorname{lnPXKC}_{\mathrm{t}}+\beta_{3} \ln \mathrm{PXKV}_{\mathrm{t}}+\varepsilon_{I E_{t}}
\end{aligned}
$$

Where:

PXKI = Indonesian exported coffee price (US\$/ton) 
PXKB = Brazilian exported coffee price (US\$/ton)

PXKI = Columbian exported coffee price (US\$/ton)

PXKV = Vietnamese exported coffee price(US\$/ton)

PIKUSA = United States imported coffee price (US\$/ton)

PIKGER = German imported coffee price (US\$/ton)

PIKITY = Italian imported coffee price (US\$/ton)

PIKJAP = Japanese imported coffee price (US\$/ton)

PIKMLY = Malaysian imported coffee price(US\$/ton)

PIKSGR $=$ Singapure imported coffee price (US\$/ton)

$\varepsilon_{I I_{t}} \quad=$ Indonesian residue-main Importir

$\varepsilon_{I E_{t}} \quad=$ Indonesian residue-main eksportir

To acknowledge the extended cointegration between residual data of $\varepsilon_{I I_{t}}$ and $\varepsilon_{I E_{t}}$, stationarities test are carried out by applying the same method as done in rooted unite test in the scale of null degree and lag null of length.

$$
\begin{aligned}
& \Delta \varepsilon_{\mathrm{II} / \mathrm{IE}_{\mathrm{t}}}=\lambda_{\mathrm{i}} \varepsilon_{\mathrm{II} / \mathrm{IE} \mathrm{t}-1}+\sum_{\mathrm{i}=1}^{\mathrm{m}} \theta_{\mathrm{i}} \Delta \varepsilon_{\mathrm{II} / \mathrm{IE} \mathrm{E}_{\mathrm{t}-1}}+\mathrm{v}_{\mathrm{i}} \\
& \Delta \varepsilon_{\mathrm{II} / \mathrm{IE}_{\mathrm{t}}}=\varepsilon_{\mathrm{II} / \mathrm{IE}_{\mathrm{t}}}-\varepsilon_{\mathrm{II} / \mathrm{IE} \mathrm{t}-1} \\
& \Delta \varepsilon_{\mathrm{II} / \mathrm{IE}_{\mathrm{t}}}=\varepsilon_{\mathrm{II} / \mathrm{IE}_{\mathrm{t}-1}}-\varepsilon_{\mathrm{II} / \mathrm{IE}_{\mathrm{t}-2}}
\end{aligned}
$$

With the hypotesis of:

$\mathrm{H}_{0}: \lambda=0$, cointegrated residual series of $\varepsilon_{\mathrm{II} / \mathrm{IE}_{\mathrm{t}}}$ are non stationeries

$\mathrm{H}_{1}: \lambda \neq 0$, cointegrated residual series of $\varepsilon_{\mathrm{II} / \mathrm{IE}_{\mathrm{t}}}$ are stationeries

\subsubsection{Error correction model}

Error correction model is carried out to understand a short-term integration. This method can be done if there is a long-term integrated relation in the cointegrated analysis. Model based on Granger's theory is that the existence of two parameters can be modified into error correction model which was introduced by Sargan (1964) cited by Hendry (1995). The model has a function of incorporating of both a short-term and long-term behavior. The analysis used to evaluate a short-term integration is that banked on error correction model approach which is formulated as follow:

$$
\begin{aligned}
& \Delta \operatorname{lnPXKI_{\mathrm {t}}}=\theta_{0}+\theta_{1} \Delta \operatorname{lnPXKB_{\mathrm {t}}}+\theta_{2} \Delta \ln \mathrm{PXKC}_{\mathrm{t}}+\theta_{3} \Delta \operatorname{lnPXKV}_{\mathrm{t}}+\theta_{4} \varepsilon_{I I_{t-1}}+v_{t} . \\
& \Delta \operatorname{lnPXKI} \mathrm{t}_{\mathrm{t}}=\sigma_{0}+\sigma \tau_{1} \Delta \ln \text { PIKUSA }_{\mathrm{t}}+\sigma_{2} \Delta \operatorname{lnPIKGER}_{\mathrm{t}}+\sigma_{3} \Delta \operatorname{lnPIKITY}_{\mathrm{t}}+\sigma_{4} \Delta \ln \mathrm{IIKJAP}_{\mathrm{t}} \\
& +\sigma_{5} \Delta \ln \text { IKMMLY }_{\mathrm{t}}+\sigma_{6} \Delta \ln \text { PIKSGR }_{\mathrm{t}}+\sigma_{7} \varepsilon_{I E_{t-1}}+u
\end{aligned}
$$

Where:

$\varepsilon_{I I t-1}=$ Cointegrated residues from the equation of Indonesia - Importir countries

$\varepsilon_{I E_{t-1}}=$ Cointegrated residues from the equation of Indonesia - Eksportir countries

$\theta_{4}$ and $\sigma_{7}=$ parameter from error correction variable.

The fulfilled requirement in these approaches are:

$\mathrm{H}_{0}: \theta_{4}, \sigma_{7}=0$,causality model with an ECM approach is classified to be valid

$\mathrm{H}_{1}: \theta_{4}, \sigma_{7} \neq 0$, causality model with an ECM approach is classified to be invalid

\section{Result and Discussion}

\subsection{Trend of Green Coffee Prices}

Table 1, in general indicates the trend of green coffee prices in average for mainly exported countries which are highest in Columbia, while the lowest is in Vietnam. Vietnamese exported price is $50 \%$ lower than Columbia (highest price). On the other side, Indonesian green coffee price is classified as moderate in which lying among exported prices, but little bit lower from the average global prices (Siddiqui 2016). The most prominent factor affecting Columbia's price to be highest is that the quality of coffee yielded and its type. As generally known that, Columbia is considered as both the major producer and exporter of arabica coffee in the world. This type tends to have a higher price in the global market compared to robusta. The growing price of exported coffee among four exported countries between 1970 and 2012 was around 3.08 to $4.43 \%$. Such a value is relatively higher compared to the imported price and situated above global price. The average price of green coffee in the Unites States, Germany, Italy, and Japan possess a low value, however the average growth per year is considered to be higher compared to other imported countries (Diaz 2009; Domeisen and Wolf 2010). 
Table 1. The average price of green coffee and its growing value in exported market and the major imported countries.

\begin{tabular}{|c|c|c|c|c|}
\hline $\begin{array}{c}\text { Coffee } \\
\text { Price }\end{array}$ & $\begin{array}{c}\text { Minimum } \\
\text { (US\$/ton) }\end{array}$ & $\begin{array}{c}\text { Maximum } \\
\text { (US\$/ton) }\end{array}$ & $\begin{array}{c}\text { Average } \\
\text { (US\$/ton) }\end{array}$ & $\begin{array}{c}\text { Averaging } \\
\text { growths (\%) }\end{array}$ \\
\hline Main exported countries & 738 & 12597 & 3182 & 4.43 \\
\hline Indonesia & 839 & 15124 & 4143 & 4.66 \\
\hline Brazil & 1469 & 16466 & 5043 & 3.34 \\
\hline Colombia & 468 & 8026 & 2531 & 3.08 \\
\hline Vietnam & 1282 & 14649 & 4568 & 2.23 \\
\hline Main imported countries & 1143 & 16343 & 4890 & 1.07 \\
\hline United States & 1106 & 13566 & 4409 & 1.72 \\
\hline German & 1432 & 16652 & 4721 & 3.14 \\
\hline Italy & 672 & 9397 & 2587 & 3.95 \\
\hline Japan & 644 & 11975 & 3350 & 5.45 \\
\hline Malaysia & 1008 & 14227 & 4133 & 2.18 \\
\hline Singapure & \multicolumn{5}{l}{} \\
\hline The world &
\end{tabular}

Source : extrapolated data

The average growth of world coffee prices from 1970 to 2012 was about 2.18 percent/year. This value is relatively lower compared to the exported price and a couple of imported price from imported countries (Dragusanu et al. 2010). Table 1, basically explains the exported price that has a higher growth compared to imported price growth. It shows that changes in the bid side are correlatively higher compared to the demand side (Mitchell et al. 2001).

In general, the trend of prices indicated the condition of both, demanded and supplied sides. The after math of globalization effect leads to the economic situation of each country being opened onto the international trade system. The fluctuation price of coffee that occurs in the global is linked to the production, weather and economic environments from the internal side (FAO 2009; Gullman 2015; Abdi 2016). The likelihood of coffee prices among markets and countries in the world are interrelated among others. The power of supplied side (export) and demanded side (import) possess an influence towards change and fluctuation of the world market price ether exported and imported countries. The effected relationship that occurs among coffee markets are delineated from the movement of prices which have a pattern that is likely be the same from 1970 to 2012 (Schubler 2009; Lewin 2004).
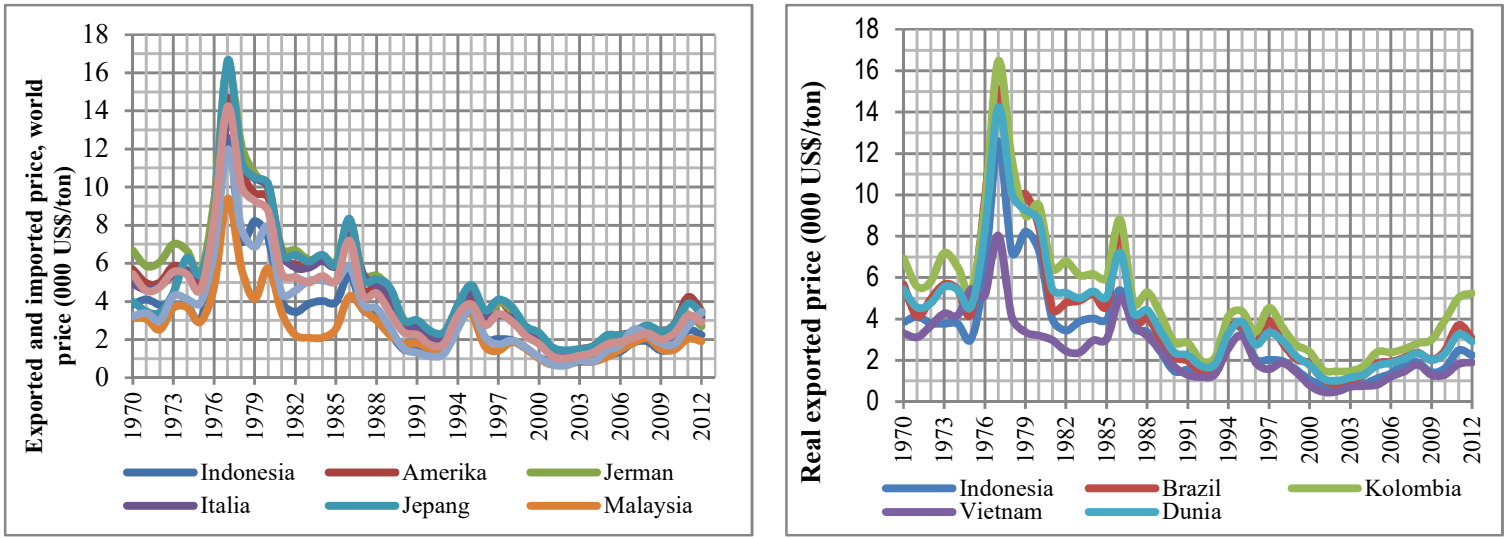

Figure 1. The trend of imported price from real exported countries (1a) and real export (1b) of coffee from 1970 to 2012 .

(Source : Extrapolated data)

In the period of 1970 to 1012 , trend of exported price in the market, imported market as well as in the world are fluctuated in line with same pattern. Figure 1, points out that in the period of 1975 to 1977, coffee price was soared compared to the previous years or after. The culminated price occurred in 1978 and after that encountered a long trend of declining (SSI Review 2014).

Imported price of green coffee in the Japanese market every year is higher compared to the world price and other imported countries' price. Otherwise, Malaysia possesses the lowest imported price. In addition, Indonesian exported coffee price is classified to be low compared to the main imported green coffee producers and the world price. The similar condition can be seen also in the exported market. Indonesian exported coffee price lays below 
exported price of Brazil and Columbia. Columbia has the highest exported price compared to other three exported countries (Brazil, Indonesia and Vietnam) as well as the world price (World Bank, 2014).

The fluctuation of green coffee prices in the world market (both imported and exported countries) experience a dramatically change that occurred in 1975 in which encountered growing period with the peak in 1977 and then declined gradually until 1985. The green coffee prices were increased in 1986 and for the next period experienced a decline to touch the lowest point in 2001. It has been affected by unbalanced between supplied sides that tend to be higher than the demanded sides which are relatively stable. In addition, growing new coffee plantations in Vietnam, increasing export from Brazil coincide with the extended plantation programs to the free frost, and increasing number of production and real devaluation in the beginning of 1999 were additionally accumulated to the decline of global coffee prices in 2001 (Hallam, 2003).

\subsection{Resulted test of stationary data}

Stationary test that carried out shows at the level I (0), there are nine of ten variables used are not stationery at the confident level of 1 percent, 5 percent, and 10 percent. It indicated by Augmented Dickey-Fuller (ADF) t-statistic value which is lower than critical value of McKinnon. The consequence of not being fulfilled towards the stationary assumption at the level of I (0), will allow the whole variables tested by integrated degree test. The variables are categorized as stationers at the first difference if ADF value tests are less than the critical value of McKinnon after once differential step tested. Stationary resulted test of each variable that used in model showed in Table 2.

Table 2. Tested results of rooted unit on exported prices (Indonesia, Brazil, Columbia, and Vietnam) and imported countries of coffee (United States, German, Italy, Japan, Malaysia, and Singapore) at the level and the first difference from 1970 to 2012.

\begin{tabular}{|c|c|c|c|c|c|c|}
\hline \multirow{2}{*}{ Variables } & \multicolumn{3}{|c|}{ Level } & \multicolumn{3}{|c|}{$1^{\text {st }}$ Difference } \\
\cline { 2 - 7 } & $\begin{array}{c}\text { ADF } \\
\text { Value }\end{array}$ & Prob* & Information & $\begin{array}{c}\text { ADF } \\
\text { value }\end{array}$ & Prob* $^{*}$ & Information \\
\hline PXKI & -2.1863 & 0.4845 & Not Stationer & -5.5731 & 0.0002 & Stationer \\
\hline PXKB & -2.2308 & 0.4609 & Not Stationer & -6.4012 & 0.0000 & Stationer \\
\hline PXKC & -1.6935 & 0.7365 & Not Stationer & 6.1759 & 0.0000 & Stationer \\
\hline PXKV & -2.8867 & 0.1771 & Not Stationer & -4.3774 & 0.0064 & Stationer \\
\hline PIKUSA & -1.9082 & 0.6326 & Not Stationer & -5.7407 & 0.0001 & Stationer \\
\hline PIKGER & -2.0645 & 0.5499 & Not Stationer & -5.7002 & 0.0002 & Stationer \\
\hline PIKITY & -1.7136 & 0.7275 & Not Stationer & -4.9092 & 0.0015 & Stationer \\
\hline PIKJAP & -2.2329 & 0.4598 & Not Stationer & -6.1318 & 0.0000 & Stationer \\
\hline PIKMLY & -3.2228 & 0.0949 & Stationer & -6.3794 & 0.0000 & Stationer \\
\hline PIKSGR & -1.6369 & 0.7610 & Not Stationer & -5.0127 & 0.0011 & Stationer \\
\hline \multirow{2}{*}{ Critical value of Mckinnon } & \multicolumn{2}{|c|}{$1 \%$} & \multicolumn{2}{|c}{$5 \%$} & & $10 \%$ \\
\cline { 2 - 7 } & \multicolumn{2}{|c|}{-6212} & -1.9489 & & -1.6119 \\
\hline
\end{tabular}

The whole variables used in this study are stationary by using intercept and tested trend which is based on Akaike information criterion (AIC), Schwarz Infomation Criterion (SIC), and Hannan Quinn Criterion (HQC). All tangible stationary variables of ADF value that always lower in number than the critical value of McKinnon, whether at the significant level of 1 percent, 5 percent, and 10 percent. Therefore can be concluded that all those ten variables possess an integrated degrees which are similar to I (1), then cointegrated analysis method can be continued.

\subsection{Indonesian cointegration with main imported countries}

There are two phases that should be undertaken by applying cointegrated test of Engle-Granger: first, by regressing equations of OLS and then gaining residue from these equations. Second, by applying an ADF method that tested through rooted unit towards residues with the same hypothesis tested to ADF rooted unit test with previous variables.

Table 3. Testing results of cointegrated residual values from rooted unit of Indonesian exported coffee price towards the main exported and imported market.

\begin{tabular}{|c|c|c|c|}
\hline Variables & ADF value & Prob* & Information \\
\hline$\varepsilon_{\mathrm{II}}(-1)$ & -5.4150 & 0.0000 & Stationer \\
\hline \multirow{2}{*}{ value of } & $1 \%$ & $5 \%$ & $10 \%$ \\
\hline & $-2,6212$ & $-1,9489$ & $-1,6119$ \\
\hline
\end{tabular}

Based on the testing results of rooted unit, there is an integration between Indonesian coffee export and imported coffee price among the main imported countries. It means that there is a likelihood of long-term trade off among variables on that model. Pricing integration between the markets show an extended relation of trading 
cooperation of coffee in both, export and import between Indonesia and the main imported countries.

In general, the United States, Germany, Italy, and Japan are among those who have become a main exported market of Indonesian coffee and within the last a couple of years, Malaysia and Singapore are also considered to be a potential market of Indonesia in particular Asian region. Since 1970 through 2012, 46 percent of Indonesian coffee export was intended for United States, Germany, and Italy's market (Neilson 2014). While, for the longterm is also can be known the magnitude of the main import of coffee price on Indonesian export of coffee price as follow:

PXKI $=-1,154+0.593$ PIKUSA +0.038 PIKGER +0.107 PIKITY-0.139 PIKJAP +0.344 PIKMLY + 0.178 PIKSGR

Base on the equation of imported prices from the United States and Malaysia, there is a highly significance of Indonesian exported coffee price. With the increase of about one percent of the United States and Malaysia, it will step up Indonesian exported coffee price about 0.593 percent and 0.344 percent respectively for the long-term period.

\subsection{Estimation of Error correction model between Indonesia-main imported countries.}

On the short-term equation, diagnostic test is tested to understand whether classic assumption of deviationis occurred. Linearity test is carried out by applying Ramsey's RESET test in which the result reveals that estimation for both models are stable or restrict non-linear hypotheses. In addition, other diagnostic resulted test indicate that the short-term estimated result has not provide an auto-correlated indication, hetero-scedasticity at its residual test is normally distributed. Therefore, based on stationary and diagnostic tests with a classic assumption, then the equation used is classified as moderately good. Statistically, Error Correction Term (ECT) or $\boldsymbol{\varepsilon}_{\text {II }}(-1)$ values are significant and negative which in turn indicate the ECM specified model which applied is valid. Such an indication portrays a transitional change of imported coffee prices in United States, Germany, Italy, Japan, Malaysia, and Singapore which straight forwardly will responded by Indonesia. The ECT value determines how fast equilibrium is fulfilled or readjusted mechanism at the balanced level. ECM estimated mechanism gained from $\boldsymbol{\varepsilon}_{\mathrm{II}}(-1)$ value which is about -0.8733 that indicates the likelihood of a short-term change, will lead to a long-term gained value of 87.33 percent in the first year and 12.67 percent occurs for the coming years. In the short term, the significant variables that will affect Indonesian exported coffee price are prices from United States, Malaysia, and Singapore.

Table 4. Estimated results of the long-term relationship between Indonesia and the main imported countries $(1970-2012)$.

\begin{tabular}{|c|c|c|c|c|c|}
\hline Variables & Coefficient & Std. Error & t-Statistic & Prob. & Information \\
\hline $\mathrm{C}$ & -0.0008 & 0.0160 & -0.0514 & 0.9593 & \\
\hline D(PIKUSA) & 0.7698 & 0.2229 & 3.4534 & 0.0015 & Significant \\
\hline D(PIKGER) & -0.0974 & 0.2833 & -0.3438 & 0.7331 & Not significant \\
\hline D(PIKITY) & 0.2077 & 0.2434 & 0.8534 & 0.3994 & Not significant \\
\hline D(PIKJAP) & -0.2074 & 0.2188 & -0.9477 & 0.3500 & Not significant \\
\hline D(PIKMLY) & 0.2689 & 0.1000 & 2.6881 & 0.0110 & Significant \\
\hline D(PIKSGR) & 0.2653 & 0.1214 & 2.1845 & 0.0359 & Significant \\
\hline$\varepsilon_{\text {II }}(-1) / \mathrm{ECT}$ & -0.8733 & 0.1764 & -4.9497 & 0.0000 & Significant \\
\hline R-squared & 0.9222 & \multicolumn{3}{|l|}{ F-statistic } & 57.5527 \\
\hline Adjusted R-squared & 0.9062 & \multicolumn{3}{|c|}{ Prob(F-statistic) } & 0.0000 \\
\hline Durbin-Watson stat & 1.8991 & & & & \\
\hline \multicolumn{6}{|c|}{ Breusch-Godfrey Serial Correlation LM Test : } \\
\hline F-statistic & 0.1794 & \multicolumn{3}{|l|}{ Prob. F } & 0.8366 \\
\hline Obs*R-squared & 0.4656 & \multicolumn{3}{|c|}{ Prob. Chi-Square } & 0.7923 \\
\hline \multicolumn{6}{|c|}{ White Heteroskedasticity Test: } \\
\hline F-statistic & 3.3279 & \multicolumn{3}{|c|}{ Prob. F } & 0.0676 \\
\hline Obs*R-squared & 39.9425 & \multicolumn{3}{|c|}{ Prob. Chi-Square } & 0.2598 \\
\hline \multicolumn{6}{|l|}{ Ramsey RESET Test: } \\
\hline F-statistic & 1.8909 & \multicolumn{3}{|l|}{ Prob. F } & 0.1784 \\
\hline Log likelihood ratio & 2.3402 & \multirow{2}{*}{\multicolumn{3}{|c|}{ Prob. Chi-Square }} & 0.1261 \\
\hline \multicolumn{3}{|l|}{ Normality test } & & & \\
\hline Jargue-Bera & 2.5341 & \multicolumn{3}{|l|}{ Prob } & 0.2817 \\
\hline
\end{tabular}

Based on table 4, glaringly seen that some significantly influenced variables towards Indonesian exported coffee price from the imported coffee price perspectiveare emanating from United States, Malaysia, and Singapore at the confident level of 5\%. It turns out that there is a positive correlation between those imported coffee prices and Indonesia exported price in the short-term period. It is portrayed by ameaningful increase of each coefficient about $1 \%$ on the exported side's countries (United States, Malaysia, and Singapore) that inevitably will step up 
Indonesian exported coffee price about $0.7698 \%, 0.2689 \%$, and $0.2653 \%$ respectively.

The United States is considered to be the world's primary export target (Fig. 2) in which most of the Indonesian coffees (91\%) are traded to that country. The magnitude of Indonesian exported volumes and integrated prices indicate an interdependence of both sides (Wahyudi and Jati 2012). Hutabarat (2006) points out green coffee price from Indonesia (West Java and Lampung) possess an intertwined retailed price in the United States market compared to Japanese and European markets (FAO 2009).Such a condition could be seen in which almost 76.98\% of changes in Indonesian exported price owing to United States imported price. The high rate of coffee trade to the US is in line with the magnitude of their demand on the world coffee markets. From the past twelve years, the average of the US total consumptions was about 1.170 .028 ton/year that claimed to be highest among other imported countries (Lewin 2004; Diaz 2009).

The high total rate of the US consumption is likely affected by their income and the demand of the industrial coffee sectors. One of the well-known coffee industries in the US is Starbucks which has a long reputation in the global coffee trade (Marcone 2004; Schubler 2009). Since established in the 90's as a global brand, it has been much influencing the global coffee market and its distributionacross the globe. The influenced trend of Starbucks was seenin 2007 through the acquisition of 5\% of the total world coffee export. Such a dynamic then bring up an alteration in either the consumptive pattern of demanded side of the US coffee that eventually influences the world market price in general and Indonesia as an exported country.

\begin{tabular}{|c|c|c|c|c|c|c|c|}
\hline \multirow{2}{*}{\multicolumn{8}{|c|}{ Singapura }} \\
\hline \multirow{2}{*}{\multicolumn{8}{|c|}{ Malaysia }} \\
\hline & & & & & & & \\
\hline & \multirow{4}{*}{$\begin{array}{l}\text { Brazil } \\
\text { Colombia } \\
\text { Indonesia } \\
\text { Vietnam } \\
\text { Lainnya }\end{array}$} \\
\hline \multicolumn{7}{|l|}{ Italia } & \\
\hline \multicolumn{7}{|l|}{ Jerman } & \\
\hline \multicolumn{7}{|l|}{ USA } & \\
\hline \multirow{2}{*}{\multicolumn{2}{|c|}{$0 \%$}} & & & & & \multirow{2}{*}{\multicolumn{2}{|c|}{$100 \%$}} \\
\hline & & $20 \%$ & $40 \%$ & $60 \%$ & $80^{\circ}$ & & \\
\hline & USA & Jerman & Italia & Jepang & Malaysia & Singapura & \\
\hline — Brazil & 30.82 & 33.41 & 33.50 & 31.62 & 12.67 & 4.16 & \\
\hline Colombia & 14.72 & 2.06 & 1.60 & 15.28 & 0.52 & 1.20 & \\
\hline Indonesia & 4.24 & 3.91 & 5.86 & 15.00 & 36.25 & 65.09 & \\
\hline Vietnam & 14.84 & 17.40 & 20.01 & 12.73 & 49.04 & 5.46 & \\
\hline Lainnya & 35.38 & 43.23 & 39.02 & 25.38 & 1.52 & 24.09 & \\
\hline
\end{tabular}

Figure 2. The major imported demand of exported markets.

(Source : Extrapolated data)

Demand of Indonesian green coffee in some main imported countries (Fig. 2) is strong particularly in Singapore and Malaysia compared to Brazil, Columbia, and Vietnam. It is likely that on account of a geographical situation, both Singapore and Malaysia are imported more in volume than others from Indonesia (Jim 2014). In addition, other closed regional agreements are also boosted the intensity of coffee trade with the ASEAN countries (Singapore and Malaysia).

\subsection{Indonesian cointegration with the main exported countries}

Cointegrated test results between Indonesian exported coffee price and the main exported markets (Brazil, Columbia, and Vietnam) reveal that ADF coefficient value is negative and significant either at the confident level of $1 \%, 5 \%$, and $10 \%$. It means the residues are stationary (Table 5). Such a condition indicates the existence of a long-term integration between Indonesian exported coffee price and the prices from Brazil, Columbia, and Vietnam as the same main exported coffee.

Table 5. Rooted unit result test (ADF test) of the cointegrated residual equations from the relationship between Indonesia and the main exported coffee.

\begin{tabular}{|l|l|l|l|}
\hline Variables & ADF Value & Prob $^{*}$ & Information \\
\hline$\varepsilon_{\mathrm{IE}}(-1)$ & -4.4587 & 0.0000 & Stasioner \\
\hline \multirow{2}{*}{ Critical value of Mckinnon } & $1 \%$ & $5 \%$ & $10 \%$ \\
\cline { 2 - 4 } & $-2,6212$ & $-1,9489$ & $-1,6119$ \\
\hline
\end{tabular}

Estimated result between Indonesian exported coffee and the main exported price in the long run reveal that Indonesian exported coffee price is significantly influenced by both Brazilian and Vietnamese's coffee prices (Yin 2014). The magnitude can be seen from the coefficients of Brazil and Vietnam which are about 0.782 and 0.221 that means by each increase of $1 \%$ price from Brazil and Vietnam's import, it will step up exported prices of Indonesian coffee of $0.782 \%$ and $0.221 \%$ in the long-term period.

Estimated result between Indonesian exported coffee and the main exported price in the long run reveal that Indonesian exported coffee price is significantly influenced by both Brazilian and Vietnamese's coffee prices (Yin 
2014). The magnitude can be seen from the coefficients of Brazil and Vietnam which are about 0.782 and 0.221 that means by each increase of $1 \%$ price from Brazil and Vietnam's import, it will step up exported prices of Indonesian coffee of $0.782 \%$ and $0.221 \%$ in the long-term period.

$$
\mathrm{PXKI}=-0.229+0.782 \mathrm{PXKB}+0.013 \mathrm{PXKC}+0.221 \mathrm{PXKV}
$$

\subsection{Indonesian Error Correction Model Estimation and the main exported countries}

Classical assumption test on the short-term estimated result relationship used ECM shows that the whole resulted equations are not auto-correlated which are indicated by the value of DW and LM. In addition, equation residues are normally distributed and the data are linear and there is no indication of heteroscedasticity. For the integrated short-term result tests between Indonesia and the main exported coffee, can been seen in the table 6 .

Tabel 6. Estimated results of the short-term relationship between Indonesia and the main imported counties $(1970-2012)$.

\begin{tabular}{|c|c|c|c|c|}
\hline Variables & Coefficient & Std. Error & t-Statistic & Prob. \\
\hline $\mathrm{C}$ & 0.001716 & 0.019086 & 0.089884 & 0.9289 \\
\hline $\mathrm{D}(\mathrm{PXKB})$ & 0.598030 & 0.158517 & 3.772659 & 0.0006 \\
\hline $\mathrm{D}(\mathrm{PXKC})$ & 0.032543 & 0.196512 & 0.165601 & 0.8694 \\
\hline $\mathrm{D}(\mathrm{PXKV})$ & 0.370433 & 0.081790 & 4.529087 & 0.0001 \\
\hline$\varepsilon_{\mathrm{IE}}(-1) / \mathrm{ECT}$ & -0.653252 & 0.141664 & -4.611272 & 0.0000 \\
\hline R-squared & 0.871042 & \multicolumn{2}{|l|}{ F-statistic } & 62.47895 \\
\hline Adjusted R-squared & 0.857101 & \multicolumn{2}{|l|}{ Prob(F-statistic) } & 0.000000 \\
\hline Durbin-Watson stat & 1.619339 & & & \\
\hline \multicolumn{5}{|c|}{ Breusch-Godfrey Serial Correlation LM Test } \\
\hline F-statistic & 2.577761 & \multicolumn{2}{|l|}{ Prob. F } & 0.0903 \\
\hline Obs*R-squared & 5.392332 & \multicolumn{2}{|c|}{ Prob. Chi-Square } & 0.0675 \\
\hline \multicolumn{5}{|c|}{ White Heteroskedasticity Test: } \\
\hline F-statistic & 1.574480 & \multicolumn{2}{|l|}{ Prob. F } & 0.1512 \\
\hline Obs*R-squared & 18.87730 & \multicolumn{2}{|c|}{ Prob. Chi-Square } & 0.1697 \\
\hline \multicolumn{5}{|l|}{ Ramsey RESET Test: } \\
\hline F-statistic & 2.626862 & \multicolumn{2}{|l|}{ Prob. F } & 0.1138 \\
\hline Log likelihood ratio & 2.958018 & \multicolumn{2}{|c|}{ Prob. Chi-Square } & 0.0855 \\
\hline \multicolumn{2}{|l|}{ Normality test } & \multirow{2}{*}{\multicolumn{2}{|c|}{ Prob }} & \\
\hline Jargue-Bera & 0.447212 & & & 0.799630 \\
\hline
\end{tabular}

Statistically, ECT value is significant which means ECM model specification that used is valid. Therefore, changes on the exported coffee from Brazil, Columbia, and Vietnam will concurrently be fully responded by Indonesia. The $\varepsilon_{\mathrm{IE}}(-1)$ value about -0.6532 literally points out that the short-term fluctuations of balance will be subsequently corrected for the long-term balance. Such a continuation will yield about $65.32 \%$ from its adjusted process which occurs in the first year and $34.68 \%$ for the subsequent years.

The influenced relations identified in the short-term equation are in line with the long-term trend of its relations. Analytical results show that Brazil and Vietnam have a significant influence towards Indonesian exported coffee price compared to Columbia at the significant level of $1 \%$. Both countries have a relatively huge influence on the changes of Indonesian exported coffee price. The increasing price from Brazil and Columbia will eventually raise the Indonesian exported coffee price about $0.5980 \%$ and $0.3704 \%$ respectively.

Such a magnified influence is likely inter twined with the potential market of both countries which are moderately dominant in the world market. Therefore, the fluctuation of prices in both will subsequently have an effect on the coffee price in Indonesia and the world markets (Wahyudi and Jati 2012; Anwar 2014). On the other hand, due to Indonesia along with Vietnam, and Brazil are grouped into a producer of Robusta coffee, then the price in Indonesia will be ineluctably influenced by other both countries (Brazil and Vietnam).

The existence of Vietnam in the international market is supported by their strong merit either in the comparative and competitive sides. Such a condition is related to the availability of natural resources, workers, and production costs which are relatively lower (Neilson 2013; Yin 2014). In addition, the promising support from the government is tangibly seen by way of dispensing fresh grants for almost 50 years in conjunction with promoting not only coffee plantations but also for the long run, it is intended to develop an extended coffee industry in the local and international bases (Gonzalez-Perez, M.A. \&Gutierrez-Viana, S. 2012). The increasing potential of exported market in Vietnam as well as the lower price of coffee over the course of decades have been prominent in strengthening Vietnam in the international market. This condition has positioned Vietnam over Columbia and Indonesia as well as influenced the international market lead by Brazil.

Columbia's influence towards less significance of Indonesian exported price is allegedly owing to the differences of coffee types which are yielded and exported. Columbia is considered as both producer and exporter 
or Arabica type in which its segment and market orientation are relatively expensive for the arabica type (Gonzalez-Perez, M.A.\&Gutierrez-Viana, S. 2012). Besides, Columbia for the past decades was more oriented in developing processed coffee that was intended for export rather than green coffee. Such a circumstance are eventually lead to changes in exported prices of Columbian coffee in which less effective in providing significant spin-off to Indonesia.

\section{Acknowledgments}

We would like to thank for support by Ministry of Research, Technology and Higher Education Indonesia and Papua University. Also, we would like to express our deep gratitude to Mr. Reinardus L Cabuy for the editing and the English manuscript proof reading service

\section{References}

Abdi A. 2016. Indonesian coffee annual report 2016. GAIN report number; ID 1616. USDA Foreign Agricultural Service.

[AEKI] Asosiasi Eksportir Kopi Indonesia. 2012. Laporan Pasar Kopi. Edisi Juli. Jakarta.

Almeida F., M., Gomes M., F., M. and Silva O., M. 2012. Non-tariff measures in international coffee trade. Poster presented in International association of Agricultural Economists, Brazil.

Anwar I. 2014. Indonesian coffee market. Association of Indonesian coffee exporters and industries.

Baffes J., Lewis B and Varangis P. 2004. Coffee; Market setting and policies. Global agricultural trade and developing countries [Chapter 16].

Barret C., B. 1996. Market Analysis Methods: Are our enriched tool kits well suited to enlivened markets. American Journal of Agricultural Economics $70: 825-829$.

Beyer J. 2008. The impacts of fair-trade coffee in producer countries. Department of economics, Charleton University. Ontario, Canada.

Cleland D. 2010. The impacts of coffee production on local producers. Full-thesis, California Polytechnic State University.

Diaz K., V. 2009. Global coffee industry; Pitfalls, successes and future perspectives. Aarhus school of business [full-thesis].

Domeisen N and Wolf J. 2010. The coffee sector in China. An overview of production, trade and consumption. Technical paper. Doc. No. SC-10-188.E. International Trade Centre, Geneva.

Dragusanu R., Giovannucci D and Nunn N. 2014. The economics of fair trade. Paper prepared for the Journal of Economic Perspectives.

Enders W. 2004.Applied econometric time series.Second Edition.Alabama,Wiley.

Engle R., F and Granger C., W., J. 1987. Co-integration and error correction: Representation, estimation, and testing,". Econometrica, Volume 55(2): 251-276.

Fitter Rand Kaplinsky R. 2001. Who gains from product rents as the coffee market becomes more differentiated? A value chain analysis.IDS bulletin paper, (Forthcoming).

Food and Agriculture Organization. 2009. The market for organic and fair-trade coffee. Study prepared in the framework of FAO project GCP-RAF-404-GER.

Gilbert C., L. 2007. Have we been mugged? Market power in the world coffee industry. Disscusion Paper No. 25. Group of research and analysis on development (GRADE).

Goletti F., Ahmed R. and Farid N. 1995. Structural determinant of market integration : The case study of rice in Bangladesh. Development Economic 33(2): 185-202.

Gonzalez-PerezM., A. and Gutierrez-Viana S. 2012. Cooperation in coffee markets: The case of Vietnam and Columbia. Journal of Agribusiness in Developing and Emerging Economies, 2(2): 57-73.

Gullman B. 2015. Rescuing the future of the international coffee trade with a voluntary certification and labelling schema. The Geo. Wash. Int'l L. Rev, Vol. 46.

Hallam D. 2003. Falling commodity prices and industry responses:Some lessons from the international coffee crisis. Commodity Market Review. Food Agricultural Organization (FAO):3 - 17.

Hutabarat B. 2006. Analisis saling pengaruh harga kopi indonesia dan dunia. Jurnal Agro Ekonomi, 24(1): 21-40.

International Coffee Organization. 2009. Opportunities and challenges for the world coffee sector. Multistakeholder consultation on coffee of the Secretary-General of UNCTAD.

Jim Y., L. 2014. Insight special; Asia coffee trade flows. Coffee business services and academy, a volcofe initiatives. ED\&F Man.

Kirnovos E. 2004.The impact of coffee market reforms on producer prices and price transmission. Development Reseach Group Trade Team, Policy Research Working Paper. The World Bank. Washington, D. C.

Kustiari R. 2007. Analisis ekonomi tentang posisi dan prospek kopi indonesia di pasar internasional[Disertasi]. Bogor.

Lewin B.,Giovannucci D and Varangis B. 2004. Coffee markets: New paradigm in global supply and demand. 
Agriculture and rural development discussion paper 3. World Bank, 1818 H Street, N.W.

Marcone M., F. 2004. Composition and properties of Indonesian palm civet coffee (kopi luwak) and Ethiopian civet coffee. Food Research International, 37; 901-912.

Marsh A. 2006. Storage of wet Arabica parchment prior to wet hulling including the storage of dry green bean coffee. GCP project.

Mitchell K., Wells P., Bancroft S and Walmsley-Smith S. 2001. Spilling the bean on the coffee trade. The Fairtrade Foundation.

Mundlak Y and Larson D., F. 1992. On the transmission of world agricultural prices. The World Bank Economic Review, 6(3): 399-422.

Neilson J. 2013. The value chain for Indonesian coffee in a green economy. Invited paper for seminar. Univ.of Sydney.

Schubler L. 2009. Protecting single-origin coffee within the global coffee market: The role of geographical indications and trademarks. The Estey Centre Journal, 10(1); 149-185.

Sethi S. 2008. Coffee as a global commodity. Phalanx No. 2 [April 2008].

Siddiqui S., R. 2016. Indonesian coffee trade to focus on niche markets as export slow. Reuters copyright.

SSI Review. 2014. Coffee market [Chapter 8].

Thomas, R., L. 1997. Modern econometrics. Addison Wesley Longman

Topik S. 2004. The world coffee market in the eighteenth and nineteenth centuries, from colonial to national regimes. Working paper No. 04-04. Univ of California, Irvine.

Tomek W and Robinson K. 1990. Agricultural product prices, Thrid Edition. New York. Cornell University Press, Ithaca.

USDA. 2016. Coffee: World markets and trade. Office of global analysis. Foreign Agricultural Service-USDA.

Wahyudi T and Jati M. 2012. Challenges of sustainable coffee certification in Indonesia. International seminar on coffee. London, United Kingdom.

World Bank. 2014. Overview of the Global Coffee Sector Supply Chains. World Bank's agriculture global practice-discussion paper. Http.www.intracen.orgThe-Coffee-Exporters-Guide---Third-Edition. 